\title{
Atividades Administrativas do Estado. O Elemento Humano
}

CORSINDIO MONTEIRO DA SILVA

Assistente Jurídico do DASP

O Estado, em sentido estrito, é uma nação encarada sob 0 ponto de vista de sua organização política ${ }^{1}$. Dentro de uma definição simples e conhecida, Estado é uma nação politicamente organizada, sendo a nação o meio próprio em que o Estado se realiza ${ }^{2}$.

A nação politicamente organizada se realiza, no Estado moderno, através de funções estatais. Para realizar suas finalidades essenciais, desenvolve o Estado um complexo de atividades, atividades essas exercidas através de três podêres: o Poder Legislativo, o Poder Judiciário e o Poder Executivo.

A cada qual dêsses podêres corresponde, de modo precípuo, uma função estatal específica, executada através de ato jurídico próprio: ao Poder Legislativo, a precípua função de legislar (função legislativa), que se executa através de ato legislativo (leis); ao Poder Judiciário, a precípua função de interpretar a lei e distribuir justiça (função jurisdicional), que se executa através de ato judicial ou jurisdicional (sentenças, decisões judiciais); ao Poder Executivo, a precípua funçâo de administrar, de concretizar em fatos objetivos, materiais, palpáveis a atividade estatal para consecução de seus encargos (função administrativa) e que se executa através de ato administrativo (decretos).

Sòmente do ponto de vista orgânico ou formal é que podemos dizer que $o$ ato administrativo corresponde a tôdas as manifestações do Poder Executivo; que o ato judicial ou jurisdicional corresponde às manifestações do Poder Judiciário e que 0 ato legislativo corresponde às do Poder Legislativo.

1 Euzébio de Queiroz Lima. Teoria do Estado, 2.ed., Freitas Bastos, Rio de Janeiro, 1953, p. 7 .

2 Euzébio de Queiroz Lima, op. cit., p.8. 
Formalmente, só cuidamos de onde, de que órgão, de que Poder emana $o$ ato.

Já no sentido objetivo ou material, tal não acontece, porquanto cada uma dessas funções nem sempre é exclusiva dêste ou daquele Poder. $O$ que se considera do ponto-de-vista material é a essência do ato, a sua natureza íntima, a sua substância.

Assim é que êste ou aquêle Poder do Estado, sob o aspecto material, pode exercer funções que não são especificamente suas. Ao baixar o Poder Executivo um regulamento, por exemplo, está a exercer ou a realizar um ato administrativo, do ponto-devista formal; porém, do ponto-de-vista material, está a executar um ato legislativo. Se êsse mesmo Poder aplica uma penalidade a um servidor público, no exercício do poder disciplinar, está a praticar um ato jurisdicional, sob o aspecto material.

Se o Poder Legislativo, ao julgar um parlamentar, cassa-lhe o mandato, formalmente está a emitir um ato legislativo; materialmente, porém, expediu um ało jurisdicional. Se êsse mesmo Poder admitiu um funcionário, exonerou-o, concedeu-lhe licença, teria praticado um ato administrativo do ponto de vista material.

Se o Presidente do Supremo Tribunal Federal - Poder Judiciário - por exemplo, conceder férias a um funcionário de sua Secretaria, ou promovê-lo, estará a praticar, materialmente, um ato administrativo, embora não se ignore que, sob o aspecto formal ou orgânico, os atos emanados daquele Poder são jurisdicionais.

De modo que os outros órgãos públicos de outros podêres também atuam em função administrativa, praticando atos administrativos. Quando assim agem, a atividade dêsses órgãos públicos se inscreve na órbita do Direito Administrativo.

Quando Laferrière afirma que o Direito Administrativo é um conjunto de regras que presidem à organização e funcionamento dos serviços públicos e que regula preponderantemente um dêsses podêres, é de se entender que o fato de ser preponderantemente implica na circunstância de regular, também, os demais podêres.

Cumpre notar que êsse nôvo ramo do Direito Público toma, se assim podemos dizer, a coloração local, informado que é pelo regime político, pela doutrina, pelo Direito positivo vigente em cada Estado, pela jurisprudência, pelos costumes. Existe, por isso mesmo, um Direito Administrativo Francês, um Direito Administrativo Japonês, um Direito Administrativo Italiano, um Direito Administrativo Brasileiro. 
Definição de Direito Administrativo que se pode reputar como das melhores é a dada pelo eminente Professor paulista Carlos S. de Barros Júnior: "Direito Administrativo é o conjunto de princípios jurídicos que disciplinam a organização e a atividade do Poder Executivo, inclusive dos órgãos descentralizados, bem como as atividades tipicamente administrativas exercidas pelos outros Podêres" 3 .

E função administrativa? Segundo aquêle Mestre, administrativa é a função pela qual os governantes expressam sua vontade com a finalidade de criar uma situação jurídica subjetiva ou de condicionar uma situação jurídica objetiva ${ }^{4}$. Caracteriza-se pela sua subordinação à lei e à moral. É uma expressão complexa, e se manifesta através de atos e fatos administrativos. Dos fatos podem decorrer efeitos jurídicos, não tanto quanto dos atos administrativos. Os fatos independem da vontade do órgão administrativo, já os atos dependem dessa vontade 5 .

Os atos administrativos dependem da execução da lei e são aquêles através dos quais o Estado determina situações jurídicas individuais ou concorre para a sua formação.

Segundo Hely Lopes Meirelles, 0 ato administrativo é atividade volitiva da Administração Pública, no exercício de suas funções próprias, visando o alcance de seus fins específicos, 0 que o distingue do fato administrativo que, em si, é atividade pública material, desprovida de conteúdo ideológico ${ }^{6}$.

Exemplo concreto de um ato administrativo: um regulamento, a nomeação, a promoção ou a demissão de um funcionário... São declarações formais da vontade do Poder Público. Declarações destinadas a produzir efeitos jurídicos, sejam êles objetivos, sejam subjetivos, em virtude da execução da lei!

Exemplo de um fato administrativo: a pavimentação de uma rua, a abertura de um túnel, a construção de uma escola, de uma ponte...

Ao conjunto de podêres cometido a cada órgão, a cada unidade jurídica, a cada instituição estatal é que se dá o nome

3 Carlos S. de Barros Júnior. Compêndio de Direito Administrativo BraSileiro. Revista dos Tribunais. São Paulo, 1966, 2. ed., p.8.

4 Carlos S. de Barros Júnior. Compêndio de Direito Administrativo. Max Limonad. São Paulo, I, p.81-2.

5 Sabino Alvarez-Gendin. Tratado General de Derecho Administrativo.
Barcelona, 1958, I, p.316.

6 Hely Lopes Meirelles. Direito Administrativo Brasileiro. Revista dos Tribunais. São Paulo, 1966, 2.ed., p.155. 
de competência. A competência imprime caráter especial a cada órgão do Estado. Caracteriza-se, cada órgão, por uma das funções, embora a competência de um órgão possa ter outras funções além daquelas que caracterizam o Poder a que pertence ${ }^{7}$.

Competência, a que nos referimos, é capacidade legal para exercer determinado ato, administrativo, jurisdicional ou legislativo. Na lição de Sarria ${ }^{8}$, o Direito Administrativo se ocupa do regime jurídico das manifestações de vontade que se produzem quando da prestação dos serviços públicos. Aduz que a manifestação de vontade é o exercício do poder de querer, e êste poder nada mais é que a competência, cuja determinação equivale a estabelecer o que poderá jurìdicamente querer 0 agente ou o indivíduo, e em que condições de tempo, de lugar ou de forma deve querer, para que a manifestação de sua vontade tenha valor jurídico.

Relativamente aos agentes públicos ou servidores, assim aquêle ilustre Mestre colombiano classifica a competência:

a) em razão das funções próprias de cada agente, ou competência funcional;

b) em razão do território de jurisdição de cada agente, ou competência territorial; e,

c) em razão do grau que cada agente possua de acôrdo com suas funções e com as divisões territoriais, ou competência hierárquica ${ }^{9}$.

Outra não é a lição de Gaston Jèze. Para êsse grande Mestre, o Direito organiza a capacidade dos indivíduos e a competência dos agentes públicos. O Direito Administrativo ocupa-se do regime jurídico das manifestaçóes de vontade produzidas por ocasião da gestão dos serviços públicos ${ }^{10}$.

O observador sempre comprovará - aduz Jèze —, através da análise jurídica, a manifestação de vontade de um indivíduo, bem como será levado sempre a determinar os resultados jurídicos que essa manifestação de vontade produz. O Direito, para Jèze, ocupa-se, exclusivamente e sempre, das manifestações de vontade.

Determinar a capacidade de um indivíduo ou a competência de um agente público equivale a estabelecer o que juridica-

7 Sabino Alvarez - Gendín, op: cit., p. 51.

8 Eustorgio Sarria, Derecho Administrativo, Bogotá, 1957, p. 26/7.

9 Eustorgio Sarria, ob. cit., p.28.

10 Gaston Jèze - Princípios Generales del Derecho Administrativo. Buenos Aires, Depalma, 1948 (trad. Julio N. San Millán Almagro), I, p.9-10 
mente poderá querer o indivíduo ou o agente, e em que condições deverá querer (condições de tempo, de lugar, de forma etc.), para que a manifestação de sua vontade tenha valor jurídico, isto é, para que a fôrça, na hipótese de não execução, compila ou obrigue a realizar os resultados jurídicos desejados.

Por isso, afirma Jèze que o Direito é, em suma, essencialmente uma regulamentação de capacidade ou de competência.

A capacidade, a competência é um poder de querer um resultado jurídico. $O$ exercício dêsse poder é a manifestação de vontade, é o ato jurídico.

Portanto - conclui Gaston Jèze -, o essencial no Direito é o ato jurídico, a saber: a manifestação da vontade, no exercício de um poder legal, para produzir um resultado jurídico. Dêsse modo ocorre em todos os ramos do Direito, assim público como privado ${ }^{11}$. Para Marcello Caetano, competência é um conjunto de po-
dêres que o órgão possui para exercer direitos subjetivos e atribuições da pessoa coletiva. Tais podêres - aduz o ilustre Mestre luso - não pertencem aos individuos investidos no papel de suporte dos órgãos, mas aos próprios órgãos ${ }^{12}$.

Dá-se a competência em razão da matéria (ratione materiae), em razão do lugar (ratione loci) e em razão do tempo (ratione temporis), a que se inclui a competência em razão do grau hierárquico.

Competência é um poder dado por lei para que o órgão cumpra sua finalidade específica. No dizer de Marcello Caetano, competência é o complexo de podêres funcionais conferido por lei a cada órgão ou cargo para o desempenho das atribuições da pessoa coletiva em que esteja integrado ${ }^{13}$. Em certo sentido, é encargo: tem que ser aceita e exercida ${ }^{14}$.

Segundo Jèze, o agente público não é livre de exercer sua competência, e, sim, tem o dever de exercê-la de conformidade $\mathrm{com}$ as normas próprias de cada serviço ${ }^{15}$. Adiante-se a lição de Marcello Caetano de que a compe-
tência é função do cargo: não direito do agente. De igual modo, 11

Op. cit. loc. cit.

12 Marcello Caetano, Manual de Direito Administrativo. 7.ed. Coimbra
Editôra, Lisboa, 1965, p.165. A expressão "pessoa coletiva" corresponde à

"Pessoa jurídica" de nosso Direito.

13 Op. et loc. cit.

14 Manoel Ribeiro. Direito Administrativo. Itapoã, Salvador, 1964, I, p.186.

15 Apud Eustorgio Sarria. Derecho Administrativo. Bogotá, 1957, p. 28. 
as honras e prerrogativas pertencem, de ordinário, ao cargo e raramente são pessoais ${ }^{16}$.

Quais, assim, as atividades do Estado no âmbito da Administração? São as suas atividades administrativas, vale dizer, a Administração Pública, em sentido estrito, sem a qual não se poderia conceber o Estado.

Aduz Marcello Caetano que " a Administração Pública não nos aparece hoje em dia como uma forma típica da atividade do Estado, mas antes como uma das maneiras por que se manifesta a sua autoridade. A Administração deixa de se caracterizar como função para se afirmar como poder" ${ }^{17}$. Esclarece-nos aquêle ilustre Mestre do Direito Administrativo que, "se definirmos genèricamente o poder como sendo a possibilidade atribuída a alguém de eficazmente impor aos outros o respeito da própria conduta ou de traçar a conduta alheia, será fácil de compreender o que queremos dizer" 18 .

Nada obstante, para fins didáticos continuaremos a chamar a êsse tipo de atividades estatais de atividades administrativas.

Desdobram-se estas atividades, como se sabe, em atividades-fins e atividades-meios.

As primeiras são as atividades específicas do Estado, em razão das quais o Estado existe. São as atividades institucionais do Estado, também chamadas funções essenciais, como, por exemplo, a defesa nacional, a declaração do direito em tese, a educação e saúde pública, a distribuição da justiça, a construção de estradas.

Atividades-meios são as atividades gerais ou instrumentais do Estado para a consecução dos seus fins, isto é, para atender aquêles objetivos - de educação, de saúde pública, de defesa nacional, de distribuição de justiça...

A Administração é a mais ampla atividade do Estado e também a fundamental, no dizer de Ranelletti ${ }^{19}$.

Para administrar, o Estado necessita de recursos. Recurso material, recurso financeiro e, acima de tudo, do elemento humano, da pessoa física, do agente da ação administrativa, que é o agente público, o funcionário público.

16 Op. cit., p.516.

17 Op. cit., p. 8.

18 Op. cit., p. 8.

19 Apud Carlos S. de Barros Júnior, op. cit., p.68. 
Do ponto de vista jurídico, a organização administrativa do Estado repousa sôbre as personalidades morais de Direito Público. Mas estas personalidades não têm vida, por assim dizer, senão através das pessoas físicas que agem em seu nome.

As pessoas jurídicas, no dizer de Laso, atuam mediante vontades humanas que se põem a seu serviço. 0 elemento humano é o nervo motor dêsses entes jurídicos ${ }^{20}$.

Nesse conjunto de atividades que constitui a Administração Pública, sobreleva a administração de pessoal pela importância que o elemento humano tem como instrumento de realização do Estado.

Êsse conjunto de pessoas a serviço das entidades estatais constitui o Funcionalismo Público, e sua atividade se regula por normas e princípios especiais.

O vínculo entre o funcionário e o Estado é de natureza estatutária, segundo o pensamento dominante. Há opiniões divergentes, como a de que o funcionário é regido por um Estatuto próprio, porém com inequívoca vinculação constitucional.

No Brasil, desde 1939, têm os funcionários seu Estatuto, que foi, primeiramente, o aprovado pelo Decreto-lei $n$ ? 1.713, de 28 de outubro daquele ano, estando hoje em vigor a Lei no 1.711 , de 28 de outubro de 1952 , que institui o regime jurídico dos funcionários civis da União e dos Territórios. Inequivocamente, o Estado tem dispensado atenções especiais ao elemento humano, isto é, ao servidor público. É evidente que ainda há muito por fazer, por melhorar, por aperfeiçoar, dentro de um processo global de desenvolvimento para o qual deverá, necessàriamente, contribuir o próprio servidor!

O Servidor Público brasileiro precisa criar consciência de Seu papel na estrutura do Estado e de que é, efetivamente, um profissional.

A dedicação do Servidor Público a seus misteres e a constante busca de aperfeiçoamento de seus conhecimentos específicos são índices de que encara com a necessária seriedade sua profissão.

O descaso, o desleixo, a negligência, o despreparo de alguns têm pôsto a perder o bom conceito de quase tôda uma laboriosa classe e amargurado a muitos pelo desencanto que thes trazem as medidas restritivas do Govêrno!

20 Enrique Sayagués Laso. Tratado de Derecho Administrativo. Montevideo, 1953, I, p.255-56. 
Nossos governantes, de um tempo a esta parte, têm trazido uma imagem estereotipada do servidor público nem sempre correspondente à realidade, porém o bastante para ensejar algumas providências constrangedoras ou mesmo arrebatadoras de certas conquistas legítimas, o que, não raro, tem repercussão aprovativa ou de indiferença na opinião pública que, do funcionário público, não faz melhor conceito, mesmo porque ninguém quer dar-se ao incômodo de distinguir para fazer justiça! Ser justo é oneroso e cansativo!

Está nas mãos dos servidores o desfazer essa falsa imagem e continuar lutando, cada qual, essa luta que acaba sendo de todos, pela reconquista urgente do prestígio, malgrado nosso, até certo ponto perdido!

Está nas mãos do Govêrno recompor o quadro, reestruturar em novas bases o funcionalismo, dando-lhe efetiva expressão profissional, hierarquizando-o dentro de critérios honestos pela competência demonstrada, pela natureza do trabalho que executa, pela dedicação revelada no cumprimento do seu dever. 